Archaeological Prospection

Archaeol. Prospect. 21, 75-86 (2014)

Published online 10 February 2014 in Wiley Online Library

(wileyonlinelibrary.com) DOI: 10.1002/arp.1476

\title{
Prospecting for New Questions: Integrating Geophysics to Define Anthropological Research Objectives and Inform Excavation Strategies at Monumental Sites
}

\author{
TIMOTHY HORSLEY ${ }^{1 *}$, ALICE WRIGHT ${ }^{2}$ AND CASEY BARRIER ${ }^{2}$ \\ 1 Horsley Archaeological Prospection, LLC; Department of Anthropology, Northern Illinois University, \\ DeKalb, IL 60115, USA \\ 2 Museum of Anthropology, University of Michigan, Ann Arbor, MI 48109, USA
}

\begin{abstract}
Geophysical data have the potential to significantly contribute to archaeological research projects when effectively integrated with more traditional methods. Although pre-existing archaeological questions about a site may be answered using geophysical methods, beginning an investigation with an extensive geophysical survey can assist in understanding the function and archaeological potential of a site, and may even transform preconceptions about the type and spatial organisation of features that are present. In this way, these prospection tools not only accurately locate and map features to allow recovery of cultural material for identification and dating, we argue that they can go much further, allowing us to prospect for new and appropriate archaeological and anthropological research questions. Such an approach is best realised when geophysical and traditional archaeologists work together to define new objectives and strategies to address them, and by maintaining this collaboration to allow continual feedback between geophysical and archaeological data. A flexible research design is therefore essential in order to allow the methodologies to adapt to the site, the results, and the questions being posed. This methodology is demonstrated through two case studies from mound sites in southeast USA: the transitional Mississippian Washausen site in Illinois; and the Middle Woodland Garden Creek site in North Carolina. In both cases, integrating geophysical methods throughout the archaeological investigations has resulted in multiple phases of generating and addressing new research objectives. Although clearly beneficial at these two mound sites in southeast USA, this interdisciplinary approach has obvious implications well beyond these temporal and geographical areas. Copyright @ 2014 John Wiley \& Sons, Ltd.
\end{abstract}

Key words: Geophysics; integrated survey; mound; southeast USA; Middle Woodland; Mississippian

\section{Introduction}

Geophysical methods have become a common part of the archaeologist's toolkit in southeastern North America, where they are increasingly utilised to explore large sites and landscapes (e.g. Kvamme, 2003; Peterson, 2007; Horsley and Wall, 2009, 2010; Thompson and Pluckhahn, 2010, 2012; Burks and Cook, 2011; Butler et al., 2011). Often, however, these non-invasive methods have been used more narrowly, to locate specific buried features for targeting in subsequent excavations. This is especially true in commercial applications

* Correspondence to: T. Horsley, Department of Anthropology, Northern Illinois University, USA. E-mail: timhorsley@gmail.com that require the production of maps of anomalies worth more invasive testing.

Although very effective in these situations, we illustrate that geophysics can be deployed to better advantage in research contexts. (This paper focuses on research-driven projects, but our approach-and geophysical surveys in general-is also amenable to commercial contexts: e.g. Johnson and Haley, 2006; Lockhart and Green, 2006). In the mid-1990s, Boucher (1996) argued that geophysical methods were not used to their full potential. Citing examples from the UK, he determined that this resulted from poor communication between geophysicists and archaeologists. Nearly two decades on, this issue is still commonplace in many regions, but recent calls for the use of non-invasive methods 'beyond mere prospection' (Conyers and Leckebusch, 2010) and for 'inquiry-based geophysics' 
(Thompson et al., 2011) show that collaborative interactions between the two methodologies can accomplish more than either strategy used in isolation. For example, although traditional methods such as surface collections, shovel testing and excavation can identify cultural material and provide diagnostic dating evidence from a subset of subsurface features, extensive geophysical survey can assist in identifying the presence (or absence), type, organisation and extent of buried features across a site, taskscape or landscape. Furthermore, groundtruthing geophysical anomalies can greatly augment and optimise the archaeological interpretation of the geophysical data (e.g. Hargraves, 2006). Just as the dating of features is impossible without groundtruthing, site-wide interpretations are impossible -or at least inefficient -- without geophysical mapping (e.g. Benech, 2007; Thompson et al., 2011).

Perhaps more significantly, geophysical results can allow archaeologists to ask new site- and landscapespecific research questions that might not be considered otherwise. The potential of geophysics for actively contributing to the construction of research design is particularly salient in the American Southeast, where anthropological archaeologists are increasingly focusing on the use of space and architecture to understand social organisation, particularly at monumental sites (e.g. Pauketat and Alt, 2003; Beck et al., 2007; Thompson, 2009; Knight, 2010; Wright and Henry 2013). This new wave of research draws on diverse bodies of theory and also requires comprehensive details about settlements and monuments as a means of inferring past social, political, economic and ideological practices. In this paper, we suggest that the scope of such research endeavours can be achieved most productively through the integration of geophysics, other archaeological methodologies and anthropological inquiry itself. We thus explicitly demonstrate multiple roles for geophysical methods: (i) as a tool for prospection; (ii) as a means of testing pre-existing archaeological questions; and (iii) as a source of extensive, site-wide data to drive new anthropological research objectives that can be addressed via feedback between the geophysical and more traditional archaeological datasets.

Below, the multiple contributions of geophysical survey to traditional archaeological strategies (and vice versa) are demonstrated by work at two very different mound sites: the transitional Mississippian Washausen (ca. AD 975-1050) site in the American Bottom, IL; and the Middle Woodland (ca. 300 BC to AD 600) site of Garden Creek in the Appalachian Summit, NC (Figure 1). Archaeological investigations at each site began with extensive geophysical surveys to encompass

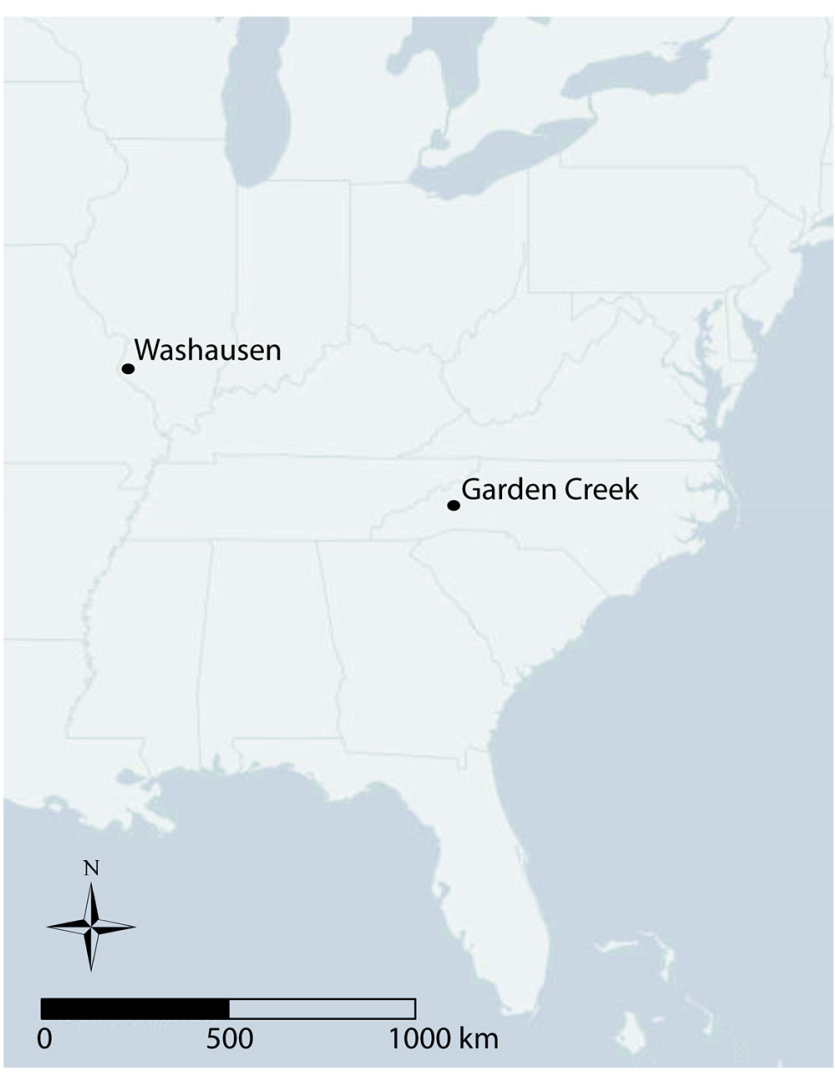

Figure 1. Locations of the Washausen site (11Mo305) and the Garden Creek site (31Hw8).

as much of the known sites as possible. This served to locate features and areas to target with subsequent excavation, as well as to obtain a comprehensive overview of the extent and organisation of cultural resources at the earliest stage of research. These initial surveys transformed existing assumptions about the sites and generated new site-specific questions. Consequently, new and appropriate research strategies were designed that combined invasive and non-invasive methodologies. Throughout the investigations, an ongoing dialogue between these geophysical and traditional approaches was maintained, in part to provide archaeological feedback from ground-truthing, but also to augment data interpretation and define new research questions and hypotheses.

\section{The Washausen site}

The Washausen mound centre (11Mo305) presents a textbook opportunity to productively employ geophysical prospection in concert with traditional strategies of survey and excavation. First recorded in the 1970s (Porter and Linder, 1974), Washausen is located 
in the Mississippi River floodplain region of the American Bottom in west-central Illinois, approximately $38 \mathrm{~km}$ south of the famous Mississippian centre of Cahokia. Unlike Cahokia, which underwent a large urban expansion and several phases of indigenous settlement reorganisation over a few centuries (Pauketat, 2004; Kelly and Brown, In press), Washausen was a relatively short-term occupation, essentially a 'single component' site. Thanks to the present-day agricultural landscape, few recent disturbances have impacted the site's subsurface features below the 0.3-m-deep modern plough zone.

Chronologically, Washausen straddles the early Mississippian transition in the region during the eleventh century AD (Kelly, 2006; Bailey, 2007; Betzenhauser, 2011). Two to three earthen platform mounds - traditionally considered a classic component of Mississippian culture - were constructed at the settlement, representing some of the earliest examples of this form of monumentality in the greater American Bottom (see Milner, 2006). Noting the potential significance of the site for addressing issues pertaining to the Mississippian emergence, over the past decade, several archaeologists have conducted fieldwork at Washausen (Burks, 2004; Kelly, 2006; Bailey, 2007; Betzenhauser, 2011; Kelly and Brown, 2012, p. 122; Barrier and Horsley, In press).

In 2011, two of the co-authors (Barrier and Horsley) began a research programme that sought to integrate geophysical methodologies into the longer-term investigative plans at Washausen. Previous work at the site informed our initial research design. Earlier geophysical surveys over portions of the site and the patterning of surface materials suggested the presence of a relatively open plaza between the remnant mounds, and provided evidence that these ploughed-down monuments were initially constructed as square-shaped platforms (see Burks, 2004; Bailey, 2007; Betzenhauser, 2011). Magnetometer surveys demonstrated the presence of the intact remains of structures and associated features below the plough zone. Of particular note, the apparent clustering of structures was reminiscent of what archaeologists refer to as 'courtyard' residential groups (Betzenhauser, 2011, p. 130). Courtyard groups, found at most American Bottom floodplain sites in the centuries leading up to the Mississippian period, typically consisted of a number of structures surrounding small community squares with central posts and pits (see Kelly, 1990a), and probably represent the material remains of co-residential corporate groups (Kelly, 2000, p. 167; Pauketat, 2003, p. 43).

With this accumulated knowledge, the Washausen Archaeological Project (WAP, directed by Barrier) was designed to contribute to an important archaeological discourse regarding community organisation during the early Mississippian transition in the American Bottom. At this time (ca. AD 1050), nucleated villages were abandoned in favour of a settlement pattern that included dispersed farmsteads and a few mound-towns (Kelly, 1990b; Emerson, 1997; Pauketat, 2004; Milner, 2006, p. xii). At new Mississippian mound centres, such as Cahokia, courtyard groups were replaced by larger residential zones oriented around plazas and mounds (Pauketat, 1994; Mehrer and Collins, 1995; Collins, 1997).

The persistence of courtyard groups at Washausen (as well as other American Bottom sites, such as those in the nearby upland Richland Complex: see Alt, 2002; Pauketat, 2003) offered an opportunity to assess the relationship between settlement and social organisation at one of the earliest Mississippian mound-and-plaza centres in the region. Therefore, we devised a plan to conduct an extensive magnetometer survey across the entire site to recover as much information as possible regarding the existence and spatial extent of Washausen's occupation. The WAP's initial research questions included: (i) what was the nature and extent of occupation at the site; (ii) is there any evidence for a nucleated settlement, potentially consisting of courtyard groups; and (iii) what is the spatial relationship between the residential occupation and the moundand-plaza complex?

After establishing a grid of 30-m squares across the centre of the Washausen site, a Bartington Grad601-2 dual fluxgate gradiometer was used to collect readings at $0.125 \mathrm{~m}$ intervals along traverses spaced $0.5 \mathrm{~m}$ apart. Alternate lines were walked in opposite directions along marked guide ropes, and the survey was extended as necessary to ensure full coverage of the occupation area, ultimately encompassing a total area of 8 ha. An extract of the results, shown in Figure 2, is presented after clipping of the data to between -30 and $30 \mathrm{nT}$, followed by destriping to remove stripes caused by heading mismatch errors between the two sensor pairs (see Horsley and Wilbourn, 2009). It was decided not to apply a stronger destriping method such as zero mean traverse, which would have reduced the plough scar responses (visible as E-W trending stripes), but produced grid-edge discontinuities in the grids containing the three large and intense ferrous responses and the broad anomalies associated with palaeochannels. Slight de-staggering $(0.06 \mathrm{~m})$ was necessary on a few select grids to correct for positional shifts between adjacent traverses, and limited edge-matching was applied to ensure smooth transitions between adjacent grids. Finally, the data were 

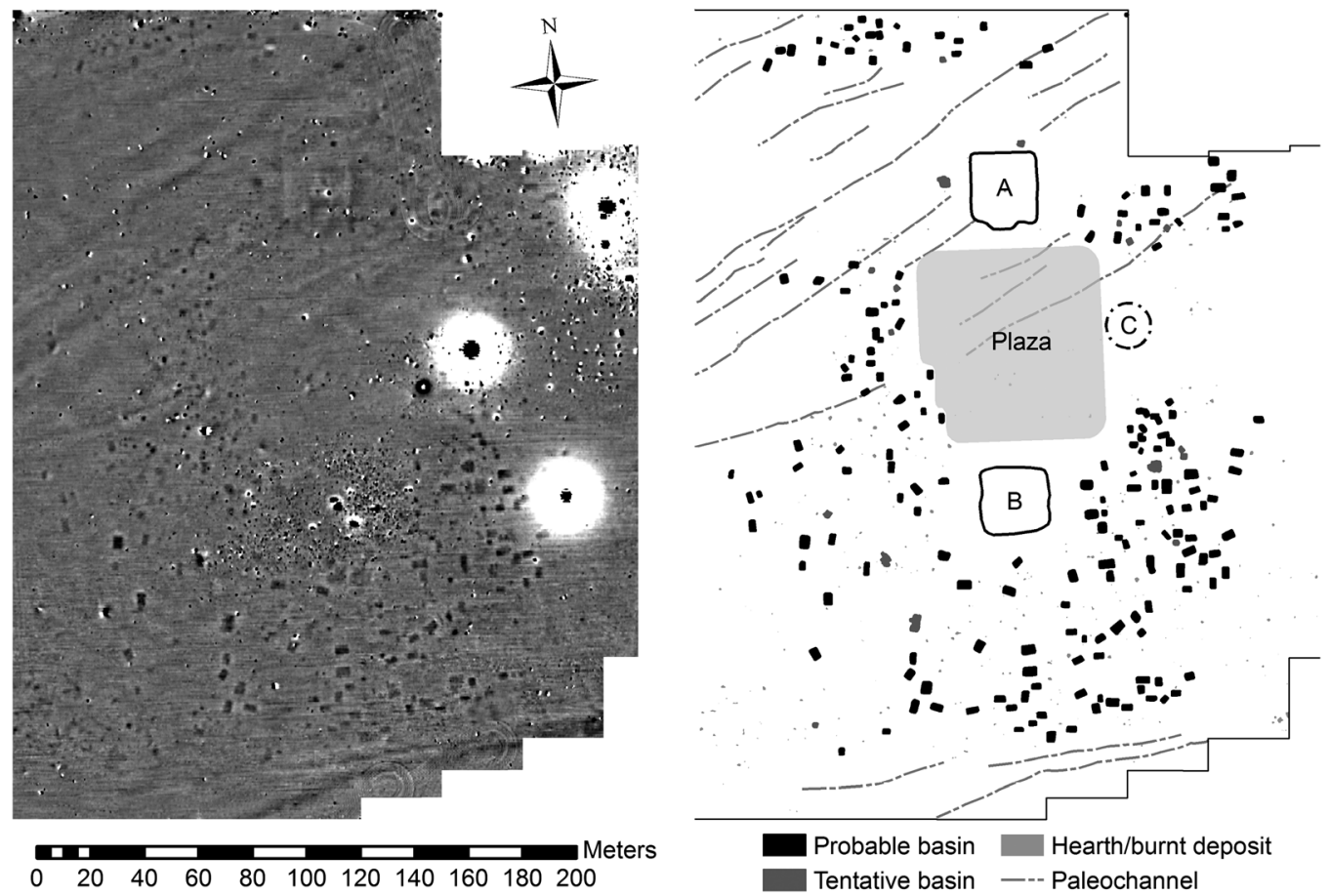

Figure 2. (Left) Extract of the Washausen site magnetometer results showing the core occupation area, plotted from -3.5 (white) to $+3.5 \mathrm{nT}$ (black). Details on data treatment and processing can be found in the text. (Right) Simplified interpretation of the same area, produced with reference to differently processed data sets and following ground-truthing.

interpolated to a resolution of $0.25 \mathrm{~m} \times 0.125 \mathrm{~m}$ (using a non-linear $\sin (x) / x$ function) to smooth the resulting image and aid interpretation.

The floodplain setting of the Washausen site provides a relatively magnetically homogeneous background, upon which it is possible to identify numerous responses of archaeological origin. These include around 200 rectangular positive anomalies, measuring up to around $4.8 \mathrm{~m}$ on the longest axis, and between $0.5 \mathrm{nT}$ and $4 \mathrm{nT}$ in strength. Such responses are consistent with being produced by the remains of basin structures, and their sizes, shapes and clustering into groups resembles excavation plans from other sites in the region (e.g. Kelly, 1990a). Other anomalies that are similar to these 'basin responses', but are weaker or non-rectangular, may represent basins that contain lower concentrations of magnetically enhanced soil (possibly indicating different functions), or might instead be due to thin spreads of midden material. Discrete and more intense positive magnetic anomalies (up to around $6 \mathrm{nT}$ ), probably indicate the locations of burnt deposits, either as hearths or pits containing burnt soil and fire-cracked rock. At the centre of these habitation anomalies, and bounded to the north by clear responses associated with Mound A, is a relatively magnetically quiet area that indicates the central plaza. A scatter of small bipolar responses (suggesting later historic activity on this slightly higher ground) largely obscures Mound B, and any trace of a potential Mound $\mathrm{C}$ is masked by an intense bipolar response that probably indicates a vertical iron pipe, such as a well.

The results therefore provide evidence for substantial occupation representing a nucleated village settlement consisting of numerous courtyard groups distributed around a central mound-and-plaza complex (Horsley and Barrier, 2011; Barrier, 2012). These findings initiated a second phase of archaeo-anthropological research designed to address the role of courtyard groups in the construction of new community identities and integrative institutions implicated by the building of monumental platform mounds and a plaza (see Barrier and Horsley, In press).

These issues were tackled through five months of targeted excavations of particular site features selected using the magnetometer results. Although the analysis of excavated materials is ongoing, these data are poised to inform us about activities occurring in and around structures, courtyard groups and public spaces (Barrier et al., 2013). For example, WAP researchers are investigating how courtyard groups used public spaces for communal ceremonies. Specifically, we are analysing faunal, botanical and sediment micromorphological samples, as well as ceramic and lithic debris and obtaining new AMS radiocarbon dates to situate the deposition of these materials in relation to events at Cahokia.

The combined geophysical and excavation results from phases one and two are being utilised to design 
yet a third phase of research to address additional questions of anthropological significance concerning: (i) the growth and development of the mound and village settlement at Washausen (see below); (ii) the nature of interactions between constituent social groups who were participants in the construction of early regional platform mounds and community institutions; and (iii) a more detailed understanding of the timing of events at the site. Importantly, the integration of data from geophysical survey, excavations and material analyses allow for an exploration of the social history of Washausen that would be impossible using any one of these approaches in isolation. For example, excavation evidence has aided reinterpretation of the magnetometer data and allowed, to some extent, the extrapolation of inferred patterns of behaviour across the entire site. In other words, our interpretations are not limited to those buildings and courtyard groups that we sampled with traditional excavation methods.

This integrated approach is allowing us to devise additional research objectives to investigate the spatial patterning of individual elements of the Washausen community and to present site-wide information about an early Mississippian mound centre in the American Bottom. For one example, the ground-truthed magnetometer data have been utilised to construct a demographic profile of the Washausen settlement (Barrier and Horsley, In press). A total of five inferred basin structures were targeted for partial excavation. These excavations confirmed the geophysical interpretation (e.g. basin dimensions and orientation), and have allowed an assessment of structure frequency and morphology across the site. With a relatively complete site map, and using established regional methodologies for calculating the number of individuals per structure based on building size, we were able to calculate a population estimate for the entire Washausen village. This information was compared to population estimates from earlier regional villages to construct a demographic profile of village growth and decline diachronically. Our knowledge of the spatial organisation of Washausen's transitional Mississippian period community allowed us to demonstrate that the creation of larger communities during the tenth and eleventh centuries $\mathrm{AD}$ resulted through frequent residential migrations as courtyard groups fissioned and re-aggregated to new communities.

This example demonstrates that feedback between geophysical and more traditional archaeological datasets can provide sources of new anthropological research objectives otherwise unattainable. Only after groundtruthed geophysical data were utilised for creation of a complete site map at Washausen was the potential for a study of regional, village demographic trajectories realised. Thus, the data collected during WAP's initial phase of prospection are still instigating new anthropological research questions, the answers to which contribute to our knowledge about Mississippian historical developments in this region. In this way, the geophysical survey has been instrumental at each phase of research, both as a tool for classic prospection and in the production of data being utilised to address issues of spatiality as well as settlement and social organisation.

\section{The Garden Creek site}

The Garden Creek site (31Hw8) in western North Carolina offered another opportunity for two of the authors (Wright and Horsley) to integrate geophysical survey and traditional field methods to answer and develop anthropological research questions. Compared with Washausen, Garden Creek presented some interesting challenges for archaeological investigation. The site is currently occupied by a suburban neighbourhood, which both obscures surface visibility and precludes extensive subsurface testing. Moreover, the clay-rich soils of the site were intensely ploughed from about 1800 to 1950, significantly impacting the site's prehistoric ground surface.

Despite these difficulties, previous research at Garden Creek indicated that the site had considerable potential for addressing questions related to the social organisation of complex hunter-gatherers. Intermittently investigated since the 1880s (Heye, 1919; Dickens, 1976; Keel, 1976), Garden Creek is best known today as the location of a platform mound (Garden Creek Mound No. 2) dating to the late Middle Woodland Connestee phase, ca. AD 200-600. Similar mounds have been identified at other Middle Woodland sites across southeast USA, where communities of hunter-gatherer-gardeners do not appear to have been organized according to institutionalised inequalities (e.g. Sears 1956; Knight, 1990, 2001; Jefferies, 1994; Lindauer and Blitz, 1997; Milanich et al., 1997; Kimball et al., 2010). This research contributes to a growing body of work in the Eastern Woodlands (e.g. Buikstra and Charles, 1999; Thompson and Turck, 2009; Sassaman, 2010; Kidder, 2011; Howey, 2012) that challenges traditional models that view monuments such as platform mounds as indicators of emergent sociopolitical hierarchies (Childe, 1950; Renfrew, 1973). To begin to understand how a relatively small-scale, egalitarian society coordinated mound building, it is important to know what institutions structured these communities in both daily practice and in communal contexts. To that end, villages and other occupation contexts are prime targets 
for archaeological inquiry. Cursory field walking survey at Garden Creek in the 1960s located a surface scatter of ceramics around Mound No. 2, which was inferred to be the remains of a contemporaneous settlement amenable to this sort of study (Keel, 1976).

Given these anthropological possibilities, the Garden Creek Archaeological Project (GCAP, directed by Wright) was initiated to situate the platform mound within the context of its surrounding occupation. The first phase of research involved an extensive, highresolution $(0.5 \mathrm{~m} \times 0.125 \mathrm{~m})$ magnetometer survey with a Bartington Grad601-2 dual gradiometer in order to assess the nature and extent of the village that was thought to surround the platform mound. Due to the potential for interference associated with the modern buildings, this was initially confined to relatively open fields, but eventually expanded to include front and back yards of private residences. Magnetometer data were collected as at the Washausen site (see above); during the preliminary season of fieldwork, approximately 4.5 ha were surveyed across the majority of the northwestern portion of the site where Middle Woodland occupation was thought to be densest. Treatment of the magnetometer data presented in Figure 3 (which includes data from both 2011 and 2012 seasons) was limited to: clipping to between -40 and $40 \mathrm{nT}$; sensor destripe (retaining plough-scar responses); and interpolation to $0.25 \mathrm{~m} \times 0.125 \mathrm{~m}$. In this image, the results are displayed at a relatively wide range of -10 to $10 \mathrm{nT}$ for reasons discussed below. Narrower display ranges were also employed when assessing and interpreting the data for different areas of the site.

Unsurprisingly, given the modern occupation, intense ferrous anomalies in excess of $\pm 20 \mathrm{nT}$ are visible throughout much of the data and potentially obscure many archaeological anomalies where present. Away from these ferrous disturbances, many of the open areas are instead dominated by magnetic disturbances resulting from recent and historic ploughing (and septic fields),

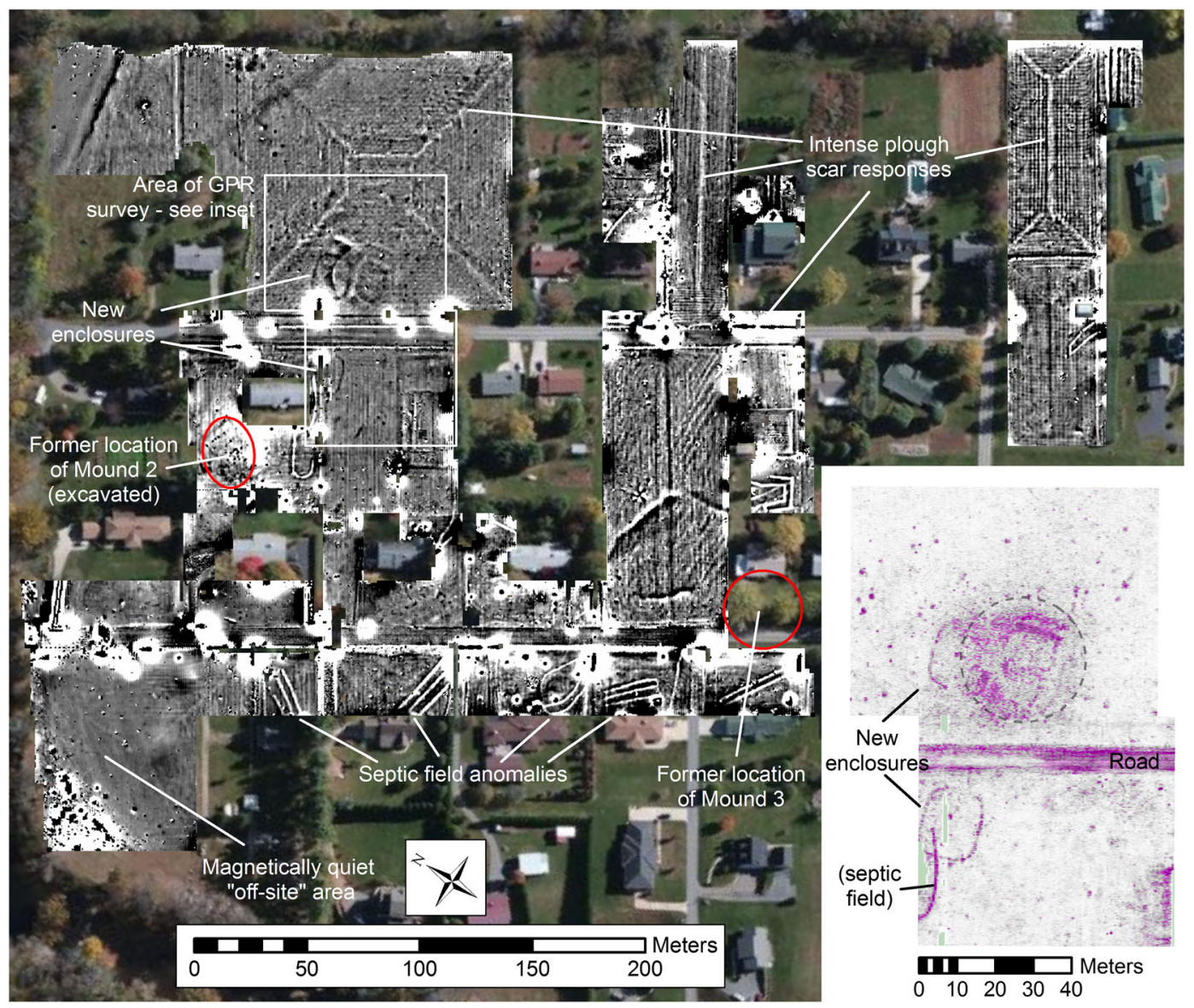

Figure 3. (Main image) Results of the Phase 1 and 2 magnetometer surveys at Garden Creek, plotted from -10 (white) to $+10 \mathrm{nT}$ (black). Base-map source: ESRI ArcGIS Online. (Inset) Composite horizontal plane map of the GPR results, combining time-slices corresponding to $0.4-0.6$ and 1.0-1.2 to illustrate reflections due to shallow and deep features, with darker shades indicating stronger amplitude reflections. The dashed ring shows the approximate extent of the low rise. Details on the treatment and processing of both data sets may be found in the text. This figure is available in colour online at wileyonlinelibrary.com/journal/arp 
substantially reducing the degree to which anomalies of archaeological origin could be distinguished. These agricultural responses are responsible for the parallel and diagonal lines that dominate the open fields and in places measure in excess of $\pm 15 \mathrm{nT}$. Clipping the data to narrower display ranges renders the results almost meaningless in these areas; however, these intense plough-scar anomalies demonstrate a strong magnetic contrast between topsoil and subsoil layers, thereby indicating areas of significant anthropogenic enhancement and consequently former occupation. Fortunately, some portions of the survey area, notably the modern-day backyards, are relatively unaffected by such magnetic noise, but even displayed at more tightly clipped ranges, the relative scarcity of anomalies interpreted as remnant habitation features is more suggestive of intermittent, non-permanent occupation, rather than the expected village. Also unexpectedly, two large geometric anomalies have been newly identified. These responses, measuring $18 \mathrm{~m}$ by $16 \mathrm{~m}$, and up to $11 \mathrm{nT}$ in strength, are roughly square-shaped with rounded corners, and in plan view they resembled small geometric enclosures that are commonly located at Adena and Hopewell sites in the Ohio Valley (e.g. Burks, 2010; Burks and Cook, 2011; Jefferies et al., 2013). To the authors' knowledge, such enclosures are, at present, unique in North Carolina and in states further south, so their discovery raised a number of important new questions.

Guided by the magnetometer results, the second phase of research at Garden Creek involved targeted excavations of several anomalies, including one of the enclosures, in order to address the following questions: (i) what types of activity took place in the so-called village area; (ii) how do these activities relate (spatially, temporally, practically) to contemporaneous monuments; and (iii) how do the monuments and occupation at Garden Creek compare to other monumental Middle Woodland sites in southeast USA and the Ohio Valley? After four months of excavations, several magnetic anomalies were successfully characterised as representing anthropogenic features dating to the Middle Woodland period. Furthermore, the westernmost geometric anomaly was interpreted as an enclosure demarcated by a steep sided, flat-bottomed ditch that extended $1.0-1.2 \mathrm{~m}$ below the ground surface (Wright, In press). These data were used to revise and enhance the interpretations of previously collected magnetometer data. By identifying sampled anomalies as pits, middens, burned features, etc., it was possible to characterise and map similar, unexcavated magnetic anomalies based on their form and intensity, thereby producing a preliminary interpretation of activities across the site (or, at least those portions not obscured by magnetic noise). Sheet midden deposits were seen to produce broad responses measuring 6-11 $\mathrm{nT}$, and pits containing high quantities of burnt soil produced anomalies as strong as 14-18 nT. Such relatively intense anomalies should be readily recognisable away from the ferrous responses, and the fact that such anomalies were only infrequently detected suggests that few causative features are present. This paucity of features (including permanent structural remains) calls into question the characterisation of the Garden Creek occupation as a true, permanent village. However, at the few known Middle Woodland settlements in the Appalachian Summit (e.g. Ela; see Wetmore, 1996), structural remains consist of scatters and alignments of small- to medium-sized postholes; compared with the basin structures at Washausen, such remains may not be resolvable in magnetometry, especially when significant magnetic disturbances are present, and may not be detectable without larger horizontal excavations. In this regard, the permanence and intensity of occupation associated with the monuments at Garden Creek remain open questions, which merit further geophysical and subsurface investigation, as discussed below.

Although this integration of geophysical and traditional archaeological data moved GCAP closer to answering the initial questions regarding the social context of the monuments at Garden Creek, the interpretive possibilities were still hampered by disturbances due to ploughing and modern iron. Fortunately, the fieldwork schedule allowed for a second phase of geophysical investigation to bring in ground-penetrating radar (GPR) and magnetic susceptibility (MS) as complementary techniques. For the GPR survey, a Sensors and Software Noggin and SmartCart system with a $250 \mathrm{MHz}$ antenna was used to survey a total of 0.9 ha. The GPR profiles were spaced $0.5 \mathrm{~m}$ apart, along which individual traces were recorded at $0.05 \mathrm{~m}$ intervals. Alternate traverses were recorded in opposite directions. For the results presented in Figure 3, data treatment comprised the application of a dewow filter, gain correction, background removal and a bandpass Butterworth filter to limit the frequency response to between 160-500 MHz. For the MS survey, a Bartington MS2B susceptibility meter and field coil were used to collect measurements of the topsoil at $5 \mathrm{~m}$ intervals across more than 10 ha.

Some of the goals in this phase of the project related explicitly to the site's monumental architecture. First, because it was only possible to excavate one of the enclosures, it was hoped that GPR would assist with identifying subsurface similarities and differences between the two enclosures to assess if they were part of an overarching earthwork design, as has been 
observed at contemporaneous Hopewell sites. Second, by conducting the GPR survey over and immediately around the two enclosures, it was possible to include a low rise adjacent to the eastern enclosure that had been observed during field walking. The aim was to help confirm its origin as anthropogenic and, if so, how it was related to the enclosure.

All of these questions were successfully answered. The GPR data, rendered into time slices, clearly revealed each enclosure in plan form, unobscured by the various disturbances that plagued previous magnetometer survey efforts (see Figure 3 inset). The results confirm the enclosures' nearly identical footprints and that the eastern enclosure is another ditch. The GPR results also show that the suspicious rise at Garden Creek is a newly identified mound and that it overlays and thus post-dates the eastern enclosure. The relative ages of these monuments cannot be further specified using currently available information, but their exact temporal relationship merits further investigation through coring, excavation and analysis of excavated materials.

The second phase of geophysical survey at Garden Creek also continued to investigate the organisation and overall size of the occupation area, this time with a greater appreciation of the challenges presented by the modern landscape. In particular, we wanted to assess the provisional interpretation of the magnetometer survey results, which suggested that this occupation might not have been a true village as initially assumed. This issue was especially saliant to our anthropological investigations of the context of Middle Woodland monumentality in general, because Middle Woodland platform mound sites in southeast USA are nearly always associated with a village midden (Knight, 2001), whereas those of the Ohio Valley are frequently characterised as 'vacant ceremonial centres' (e.g. Prufer, 1964; Dancey and Pacheco 1997; Bernardini, 2004). Expanded magnetometer survey across an additional 2.5 ha, complemented by MS survey, helped to address this issue. Overall, the effects of ploughing still limited the effectiveness of magnetometry, although potentially significant anomalies were identified more than $200 \mathrm{~m}$ away from Mound No. 2, far beyond Keel's proposed village boundary. Again, further investigation will be required to obtain essential dating evidence.

Enhanced magnetic susceptibility readings to the south of Mound 2 (120-240 × 10 $0^{-5}$ SI compared with $40 \times 10^{-5}$ SI for apparently 'off-site' areas), suggest that this might have been an area of relatively high activity, possible occupation - a possibility that will also require verification through more intrusive methods.
Although the original magnetometer survey revealed only a few large, discrete responses, these new results may indicate the presence of a settlement consisting of small features, single-post structures and dispersed midden deposits too small and subtle to be detected using this method. More broadly, MS values are elevated across a large portion of the landform in which ploughing obscured magnetometer results (reaching $300 \times 10^{-5} \mathrm{SI}$ in places, dropping off to below $40 \times 10^{-5} \mathrm{SI}$ to the northwest and southeast). These higher MS values do not correspond to known variations in geology or soil type, and although there are observable differences between gardens and hayfields, differences in land use do not easily explain the general trend. Without ground-truthing, it is impossible to say if these signatures are the result of anthropogenic activity, and furthermore, if they are contemporaneous with the construction and use of Mound No. 2. Nevertheless, these results offer exciting ground for continued integration of geophysical and traditional archaeological data at Garden Creek, as a means of assessing its occupation both over time and in comparative perspective.

Finally, by providing a clearer view of subsurface deposits below the plough zone, GPR made it possible to more thoroughly characterise the organisation of off-monument activity at the site. Particularly south and east of the eastern enclosure, numerous discrete reflections were identified, and although groundtruthing of these features has yet to be conducted, it seems likely that many of them are negative features such as storage and refuse pits, depressed hearths and burned areas, and perhaps even large postholes. The presence of such materials in this area would mean that the areal extent of the occupation at Garden Creek was far greater than suggested in the 1960s. Moreover, if other 'noisy' portions of the magnetometer survey area are also proven to have dense concentrations of features below the plough zone, then the local occupation would be one of the largest preColumbian settlements in the Appalachian Summit, much less a pre-agricultural, Middle Woodland one.

At present, these ideas hinge on the contemporaneity of the hypothetical deposits -- a fact that cannot be ascertained without a considerable amount of ground-truthing. Nevertheless, our current knowledge about Garden Creek has allowed us to posit reasonable answers to certain research questions and to develop entirely new research objectives. In addition to attempting to contextualise a local monumental phenomenon (i.e. the platform mound), ongoing research at Garden Creek is now exploring patterns of interaction between the Appalachian Summit, the Ohio Valley and the Deep South during the Middle Woodland period 
(Wright, In press). These connections, which are part of a broader anthropological discourse on pre-Columbian interaction and history making (e.g. Sassaman, 2010; Kidder, 2011), may have gone unappreciated if not for the combination of extensive geophysical survey with traditional excavation and, crucially, a flexible and evolving research design.

\section{Discussion}

These two case studies illustrate several ways that geophysical surveys - and their results - can be integrated throughout the course of an archaeological investigation. At both sites, the value of geophysics for prospection went well beyond simply locating subsurface features to excavate, although this step nevertheless played a crucial role. For one thing, the initial geophysical surveys at both Washausen and Garden Creek were designed to address, and then successfully answered, specific archaeological questions related to site extent and spatial organisation (as Thompson et al. (2011) have previously demonstrated). Both case studies show the value of undertaking extensive geophysical survey at the outset of an archaeological project for understanding the function and archaeological potential of a site. Just as importantly, though, our extensive surveys allowed new sets of both archaeological and anthropological objectives to be framed. In other words, by better understanding and appreciating the components of these sites, we defined new research questions and were able to design appropriate strategies to answer them. At Washausen and Garden Creek, this approach has demonstrated how preconceptions and even misconceptions about a site can be re-evaluated and explored anew.

In both projects, a flexible research strategy was essential to allow the methodologies to adapt to the site and questions at hand. Although both investigations began with an extensive geophysical survey, subsequent research questions and strategies were informed by the nature of the archaeological deposits as well as the salient anthropological topics of interest. In the case of Washausen, for example, the discovery of a substantial, nucleated village occupation associated with an early mound-and-plaza complex shifted the focus of research away from exploration into the mounds themselves and towards the off-mound residential zones of the site. The confirmation of the presence of courtyard groups at the site also meant that any anthropological questions going forward must consider why and how community members maintained certain aspects of previous cultural ways of life while participating in the active construction of new, Mississippian communities. Meanwhile, at Garden Creek, the challenges of the site's setting demanded the application of multiple prospection techniques throughout the course of fieldwork. These shifts in technology were matched by shifts in investigative focus. For example, initial surveys designed to explore the 'space between monuments' and to situate a platform mound within its broader social context actually revealed additional monuments in the form of ditched enclosures. Although unexpected, these and other results opened lines of inquiry that merit as much anthropological consideration as our initial research questions.

Similarly, both WAP and GCAP benefited from ongoing collaboration between their key members. In addressing broad anthropological questions, both projects demanded a background in local culture histories, familiarity with relevant bodies of anthropological and archaeological theory and expertise in applying multiple geophysical techniques (including data processing and interpretation), as well as traditional archaeological methods. Although other strategies are certainly possible, at Garden Creek and Washausen the authors found that these requirements were best met through continual interdisciplinary dialogue between anthropological archaeologists (Barrier and Wright) and a geophysical archaeologist (Horsley), and that our collaborations considerably augmented what either party could do in isolation. In practice, these collaborations involved regular feedback between geophysical and traditional archaeological results, and frequent reinterpretation of certain datasets in light of new findings. For example, at both sites, initial magnetometer results were used to identify anomalies to target in excavation. Ground-truthing was essential to confirm and support the initial interpretations (e.g. structures, pits, ditches, etc.), but by reintegrating excavation results with geophysical maps, we were able to characterise other features with similar signatures, and thus able to understand site-wide patterns of activity and occupation. In addition to framing new directions for the analysis of geophysical data, excavation results at Garden Creek were also used to guide further geophysical fieldwork. As subsurface testing of and around the Garden Creek enclosures did not clarify what kind of occupation was present (i.e., permanent settlement, aggregation site, vacant ceremonial centre), GPR and MS surveys were undertaken to obtain complementary views of the site's deposits. As discussed above, the results allow for some intriguing preliminary interpretations even as they generated yet more research questions. Answering these will involve more ground-truthing and, in turn, more collaboration between traditional and geophysical methods and interpretation. 
Finally, these case studies highlight how specific techniques were dependent on many factors, including the type of site, ground conditions, and time and budget constraints. Given these variables, it is unlikely that any two research designs will be identical at the outset of a project. However, recognising the diversity of appropriate research designs can and should encourage archaeologists to maintain flexibility over the course of their investigations, and to adjust their research strategies according to new findings and new possibilities. In this regard we consider our collaborations as much about prospecting for research questions as about prospection for archaeological remains. That is not to say that these projects were initiated without direction or a particular research focus, but rather that we remained open to explore new questions through new applications as the opportunities arose. Although this strategy may not be appropriate for all contexts (e.g. projects where research is not the primary objective), it does provide an avenue for both methodological and theoretical innovation that stands to contribute to both archaeological geophysics and anthropological archaeology in a range of research and for-profit settings.

\section{Conclusions}

Full integration of geophysical techniques throughout the course of an archaeological research project can significantly contribute to the understanding of archaeological resources at monumental sites and beyond. Although this paper focuses on a Middle Woodland site and a transitional Mississippian mound site in southeast USA, the collaborative approach we adopted clearly has implications and applications elsewhere. Regardless of temporal or geographical area, ongoing feedback between geophysical and traditional methodologies, accompanied by a flexible research design, encourages adaptations to the specific nature of, conditions at, and research potential of a site or region as the research progresses. In our experience, this approach benefited from continual dialogue between specialists.

The benefits of an early, extensive geophysical survey are self-evident. Not only are these non-invasive tools uniquely suited to prospect for subsurface archaeological features, but as we suggest, they also have considerable potential for prospecting for new research objectives. Being able to target specific features and deposits in order to obtain dating evidence and cultural materials still remains a key role for geophysical applications. However, the ability for geophysics to potentially transform previous ideas about a site and open up new and improved ways of looking at settlements and landscapes are arguably just as significant - if not more so.

In short, our southeast USA case studies highlight three critical contributions of geophysical methods to anthropological archaeology (and vice versa). First, geophysics can be used to locate and map archaeological deposits, in the traditional sense of prospection. Second, it can be carried out at multiple scales to answer specific archaeological questions (Thompson et al., 2011) and to contextualise a site in space and, in turn, in a broader social setting (Kvamme, 2003). Third, as we introduce here, geophysical techniques offer an efficient way to generate additional anthropological questions at the site level, or across a landscape or region. Importantly, although they have been shown to answer questions in their own right, geophysical data have the potential to say much more when effectively integrated with other archaeological approaches. In this regard, interdisciplinarity and continual feedback between geophysical and archaeological strategies have the potential to make significant contributions across the traditional boundaries of both fields.

\section{Acknowledgements}

Research at Washausen and Garden Creek was supported by: the National Science Foundation (Doctoral Dissertation Improvement Grants Nos BCS-1339216 and BCS-1225872, respectively); the James B. Griffin Endowment; the Museum and Department of Anthropology and Rackham Graduate School of the University of Michigan; and at Garden Creek, the Arts of Citizenship Program for Public Scholarship at the University of Michigan. We thank Rob Beck, John Kelly and Scott Ashcraft for their advice and feedback on our research projects, and Patrick Livingood, Maureen Meyers, Victor Thompson and Larry Conyers for their helpful comments on an earlier draft of this paper. We also thank the teams that supported us in the field, especially Ashley Schubert, Shaun Lynch, Jess Beck, Kevin Garrett, Christina Sampson, Travis Williams, Erika Loveland, Sophia Reini, Claire Talbert, James Scott, Jim Mertz, Rita Pelczar and John Wright. Finally, neither project would have been possible without the patience and generosity of local landowners: in North Carolina, the Cathey, Worley, Warren, Anspach and Plott families; and in Illinois, the Hawkins and Clark families.

\section{References}

Alt SM. 2002. Identities, traditions, and diversity in Cahokia's uplands. Midcontinental Journal of Archaeology 27(2): 217-235.

Bailey KS. 2007. Washausen Mound Center (11MO305) Ceramic Assemblage: Broken Pots from the Plaza. 
Unpublished Master's thesis, Department of Anthropology, Washington University: Saint Louis, Missouri.

Barrier CR. 2012. 11th century community organisation in the central American Bottom: a glimpse at the social groups and institutional trajectories of a Mississippian history. Paper presented at the 69th Annual Meeting of the Southeastern Archaeological Conference: Baton Rouge, LA.

Barrier CR, Horsley TJ. In press. Shifting communities: demographic profiles of early village population growth and decline in the central American Bottom. American Antiquity.

Barrier CR, Parker KE, Kelly LS. 2013. Preliminary results from the 2011 excavations at the Washausen Mound site, American Bottom, Illinois. Paper presented at the 70th Annual Meeting of the Southeastern Archaeological Conference: Tampa, FL.

Beck RA, Bolender DJ, Brown JA, Earle TK. 2007. Eventful archaeology: the place of space in structural transformation. Current Anthropology 48(6): 833-860. DOI: 10.1086/ 520974.

Benech C. 2007. A new approach to the study of city planning and domestic dwellings in the ancient Near East. Archaeological Prospection 14(2): 87-103. DOI: 10.1002/ arp.306.

Bernardini W. 2004. Hopewell geometric earthworks: a case study in the referential and experiential meaning of monuments. Journal of Anthropological Archaeology 23(3): 331-356. DOI: 10.1016/j.jaa.2004.06.001.

Betzenhauser A. 2011. Creating the Cahokian community: the power of place in Early Mississippian political dynamics. Unpublished PhD dissertation, Department of Anthropology, University of Illinois: Urbana.

Boucher AR. 1996. Archaeological feedback in geophysics. Archaeological Prospection 3: 129-140.

Buikstra J, Charles DK. 1999. Centering the ancestors: cemeteries, mounds, and sacred landscapes of the ancient North American midcontinent. In Archaeologies of Landscape: Contemporary Perspectives, Ashmore W, Knapp AB (eds). Blackwell: Malden, MA; 201-228.

Burks J. 2004. Results from a Small Magnetic Survey at the Washausen Site, Monroe County, Illinois. Report No. 2004-27. Ohio Valley Archaeological Consultants. Submitted to John E. Kelly, Central Mississippi Valley Archaeological Research Institute: Columbia, Illinois.

Burks J. 2010. Rediscovering prehistoric earthworks in Ohio, USA: it all starts in the archives. In Landscapes Through the Lens: Aerial Photographs and Historic Environment, Cowley DC, Standring RA, Abicht MJ (eds). Oxbow Books: Oxford; 77-87.

Burks J, Cook RA. 2011. Beyond Squier and Davis: rediscovering Ohio's earthworks using geophysical remote sensing. American Antiquity 76(4): 667-689. DOI: 10.7183/0002-7316.76.4.667.

Butler BM, Clay RB, Hargrave ML, Peterson SD, Schwegman JE, Schwegman JA, Welch PD. 2011. A new look at Kincaid: magnetic survey of a large Mississippian town. Southeastern Archaeology 30(1): 20-37.

Childe VG. 1950. The urban revolution. The Town Planning Review 21(1): 3-17.

Collins JM. 1997. Cahokia settlement and social structures as viewed from the ICT-II. In Cahokia: Domination and Ideology in the Mississippian World, Pauketat TR, Emerson TE (eds). University of Nebraska Press: Lincoln; 124-140.
Conyers LB, Leckebusch J. 2010. Geophysical archaeology research agendas for the future: some groundpenetrating radar examples. Archaeological Prospection 17(2): 117-123. DOI: 10.1002/arp.379.

Dancey WS, Pacheco PJ. 1997. A community model of Ohio Hopewell settlement. In Hopewell Community organisation, Dancey WS, Pacheco PJ (eds). Kent State University Press: Kent, OH; 3-40.

Dickens RS. 1976. Cherokee Prehistory: the Pisgah Phase in the Appalachian Summit Region. University of Tennessee Press: Knoxville.

Emerson TE. 1997. Cahokia and the Archaeology of Power. University of Alabama Press: Tuscaloosa.

Hargraves, ML 2006. Ground truthing the results of geophysical surveys. In Remote Sensing in Archaeology, Johnson, JK (ed). The University of Alabama Press: Tuscaloosa; 269-304.

Heye GG. 1919. Certain Mounds in Haywood County, North Carolina. Museum of the American Indian Heye Foundation: New York.

Horsley TJ, Barrier CR. 2011. A geophysical approach to understanding settlement organisation: a case study at the Washausen Site (11Mo305). Poster presented at the 68th Annual Meeting of the Southeastern Archaeological Conference: Jacksonville, Florida.

Horsley TJ, Wall RD. 2009. Archaeological evaluation of alluvial landscapes in Western Maryland, USA (extended abstract). ArcheoSciences, Revue d'archéométrie 33(supplément): 85-87.

Horsley TJ, Wilbourn D. 2009. Destriping linears - a new approach to an old problem. ISAP News (The Newsletter of the International Society for Archaeological Prospection) 21: $3-5$.

Horsley TJ, Wall RD. 2010. Archaeological evaluation of alluvial landscapes in Western Maryland. Report on file at the Maryland Historical Trust, Crownsville, MD.

Howey MCL. 2012. Mound Builders and Monument Makers of the Northern Great Lakes, 1200-1600. University of Oklahoma Press: Norman.

Jefferies RW. 1994. The Swift Creek site and Woodland platform mounds in the southeastern United States. In Ocmulgee Archaeology, 1936-1986, Hally DJ (ed). University of Georgia Press: Athens; 71-83.

Jefferies RW, Milner GR, Henry ER. 2013. Winchester Farm: a small Adena enclosure in central Kentucky. In Early and Middle Woodland Landscapes of the Southeast, Wright AP, Henry ER (eds). University Press of Florida: Gainesville; 91-107.

Johnson JK, Haley BS. 2006. A cost-benefit analysis of remote sensing application in cultural resource management archaeology. In Remote Sensing in Archaeology, Johnson JK (ed). The University of Alabama Press: Tuscaloosa; 33-46.

Keel BC. 1976. Cherokee Archaeology: a Study of the Appalachian Summit. University of Tennessee Press: Knoxville.

Kelly JE. 1990a. Range site community patterns and the Mississippian emergence. In The Mississippian Emergence, Smith BD (ed). Smithsonian Institution Press: Washington, DC; 67-112.

Kelly JE. 1990b. The emergence of Mississippian culture in the American Bottom region. In The Mississippian Emergence, Smith BD (ed). Smithsonian Institution Press: Washington, DC; 113-152. 
Kelly JE. 2000. The nature and context of Emergent Mississippian cultural dynamics in the greater American Bottom. In Late Woodland Societies: Tradition and Transformation across the Midcontinent, Emerson TE, McElrath DL, Fortier AC (eds). University of Nebraska Press: Lincoln; 163-175.

Kelly JE. 2006. Washausen and the 'Big Bang': understanding the context of the ripple effect. Paper presented at the 63rd Annual Meeting of the Southeastern Archaeological Conference: Little Rock, AR.

Kelly JE, Brown JA. 2012. In search of cosmic power: contextualizing spiritual journeys between Cahokia and the St. Francois Mountains. In Archaeology of Spiritualities, Rountree K, Morris C, Peatfield AAD (eds). Springer-Verlag: New York; 107-129.

Kelly JE, Brown JA. In press. Cahokia: the processes and principles of the creation of an early Mississippian city. In Making Ancient Cities: Space and Place in Early Urban Societies, Creekmore AT, Fisher KD (eds). Cambridge University Press: Cambridge, UK.

Kidder TR. 2011. Transforming hunter-gatherer history at Poverty Point. In Hunter-Gatherer Archaeology as Historical Process, Sassaman KE, Holly D (eds). University of Arizona Press: Tucson; 95-119.

Kimball LR, Whyte TR, Crites GD. 2010. The Biltmore Mound and Hopewellian mound use in the Southern Appalachians. Southeastern Archaeology 29(1): 44-58.

Knight VJ. 1990. Excavation of the Truncated Mound at the Walling Site: Middle Woodland Culture and Copena in the Tennessee Valley. Office of Archaeological Research, Alabama State Museum of Natural History: Huntsville.

Knight VJ. 2001. Feasting and the emergence of platform mound ceremonialism in eastern North America. In Feasts: Archaeological and Ethnographic Perspectives on Food, Politics, and Power, Dietler M, Hayden B (ed). Smithsonian Institution Press: Washington, DC; 239-254.

Knight VJ. 2010. Mound Excavations at Moundville: Architecture, Elites, and Social Order. University of Alabama Press: Tuscaloosa.

Kvamme KL. 2003. Geophysical surveys as landscape archaeology. American Antiquity 68(3): 435-458. DOI: $10.2307 / 3557103$

Lindauer O, Blitz JH. 1997. Higher ground: the archaeology of North American platform mounds. Journal of Archaeological Research 5(2): 169-207. DOI: 10.1007/ BF02229110.

Lockhart JJ, Green, TJ. 2006. The current and potential role of archaeogeophysics in cultural resource management in the United States. In Remote Sensing in Archaeology, Johnson, JK (ed). The University of Alabama Press: Tuscaloosa; 17-32.

Mehrer MW, Collins JM. 1995. Household archaeology at Cahokia and its hinterlands. In Mississippian Communities and Households, Rogers JD, Smith BD (eds). University of Alabama Press: Tuscaloosa; 32-57.

Milanich JT, Cordell AS, Knight VJ, Kohler TA, SiglerLavelle BJ. 1997. Archaeology of Northern Florida A.D. 200-900: The McKeithen Weeden Island Culture. University Press of Florida: Gainesville.

Milner GR. 2006. The Cahokia Chiefdom: The Archaeology of a Mississippian Society. Reprint. University Press of Florida: Gainesville.
Pauketat TR. 1994. The Ascent of Chiefs: Cahokia and Mississippian Politics in Native North America. University of Alabama Press: Tuscaloosa.

Pauketat TR. 2003. Resettled farmers and the making of a Mississippian polity. American Antiquity 68(1):39-66. DOI: $10.2307 / 3557032$.

Pauketat TR. 2004 Ancient Cahokia and the Mississippians. Cambridge University Press: Cambridge.

Pauketat TR, Alt SM. 2003. Mounds, memory, and contested Mississippian history. In Archaeologies of Memory, Van Dyke R, Alcock SE (eds). Wiley-Blackwell: New York; 151-179.

Peterson S. 2007. Surface mapping and subsurface imaging of the Mann archaeological site (12-Po-2), Posey County, Indiana. HPF 21517-11 Report on file at the Indiana Department of Natural Resources, Division of Historic Preservation Archeology.

Porter JW, Linder J. 1974. An archaeological survey of the Mississippi Valley in St. Clair, Monroe, and Randolph counties. In Preliminary Report of the 1973 Historic Sites Survey Archaeological Reconnaissance of Selected Areas in the State of Illinois. Illinois Archaeological Survey: Urbana; 28-34.

Prufer OH. 1964. The Hopewell complex of Ohio. In Hopewellian Studies, Caldwell JR, Hall RL (eds). Scientific Papers Volume 12, Illinois State Museum: Springfield; 35-83.

Renfrew C. 1973. Monuments, Mobilization and Social organisation in Neolithic Wessex. Duckworth: London.

Sassaman KE. 2010. The Eastern Archaic Historicized. AltaMira: New York.

Sears WH. 1956. Excavations at Kolomoki: Final Report. University of Georgia Press: Athens.

Thompson VD. 2009. The Mississippian production of space through earthen pyramids and public buildings on the Georgia coast, USA. World Archaeology 41(3): 445-470. DOI: 10.1080/00438240903112435.

Thompson VD, Pluckhahn TJ. 2010. History, complex hunter-gatherers, and the mounds and monuments of Crystal River, Florida, USA: a geophysical perspective. The Journal of Island and Coastal Archaeology 5(1): 33-51. DOI: $10.1080 / 15564890903249811$

Thompson VD, Pluckhahn TJ. 2012. Monumentalization and ritual landscapes at Fort Center in the Lake Okeechobee Basin of South Florida. Journal of Anthropological Archaeology 31(1): 49-65. DOI: 10.1016/j.jaa.2011. 10.002 .

Thompson VD, Turck JA. 2009. Adaptive cycles of coastal hunter-gatherers. American Antiquity 74(2): 255-278.

Thompson VD, Arnold PJ, Pluckhahn TJ, Vanderwarker AM. 2011. Situating remote sensing in anthropological archaeology. Archaeological Prospection 18(3): 195-213. DOI: 10.1002 /arp.400.

Wetmore RY. 1996. The Connestee Component of the Ela Site (31SW5). In Upland Archaeology in the East, Symposium 5. Barfield EB, Barfield MB (eds). Archaeological Society of Virginia: Richmond; 22-237.

Wright AP. In press. History, monumentality, and interaction in the Appalachian Summit Middle Woodland. American Antiquity.

Wright AP, Henry ER (eds). 2013. Social Landscapes and the Early and Middle Woodland Southeast. University Press of Florida: Gainesville. 